\title{
Trade Liberalization and Wage Inequality: A Panel Regression Model.
}

\author{
Hossam Eldin Mohammed Abdelkader \\ Assistant Professor of Economics \\ Faculty of Commerce-Ain Shams University
}

\begin{abstract}
This paper is trying to answer an old question Does trade liberalization lead to higher wage inequality? To answer this question, I used a sample of 27 countries during 10 years, 1987-1996. Panel data regression model technique is used to estimate this relationship. The results of estimated models show that in low-income and lower-middle income countries, an increase in trade liberalization leads to higher level of wage inequality, and it is significant in case of lower-middle income countries. However, I upper-middle income and high income countries, the higher trade liberalization the lower wage inequality is. Furthermore, the rise in female share in labor market decrease the wage inequality, and higher level of employment in leading sector of production, i.e. industry or agriculture, enhance the wage equality in the economy. Although, the effect of urban population size on wage inequality is ambiguous.
\end{abstract}

Key Words: Trade liberalization, wage inequality, and panel regression.

JEL: F16, C23.

Email: drhos620@,commerce.asu.edu.eg; drhos620@gmail.com 


\section{Introduction}

The increase trend in wage inequality in many countries in the last decades was a question that many economists try to find a reasonable explanation of it. One of the causes of the increase in wage inequality is the change in the structure of labor demand in favor of skilled workers, which is reflected in the increase of wages of highly educated individuals and, in the rise in unemployment among individuals with fewer qualifications (Gottschalk \& Smeeding, 1997). The recent empirical evidences show a relationship between an increase in international trade and wage inequality, which has led several economists to think that recent trade openness of economies has contributed to the increase in the wage inequality in many countries. This idea was supported by the theorems of Heckscher, Ohlin, Stolper, and Samuelson (Arbache, 2001).

The experience of trade reform in many developing countries is quite varied, but understanding the effect of trade reform on labor markets can be a complex task due to many reasons. One of these reasons, many of these countries have recently applied structural adjustments, as a result of the international economic crises at the end of the 1970s and the beginning of the 1980s. Many developing countries adopted programs of structural adjustment as a remedy of the imbalances at the macroeconomic level. Many years later, these countries adapted economic reform programs, that were involving trade liberalization, which caused rapid and extensive changes to their economies. The trade liberalization in some of these countries is associated with an increase in the returns to human capital and a high level of wage inequality. Because the developing countries have abundant unskilled labor, so they should specialize in production of intensive unskilled labor goods, thus increasing the relative demand for this factor and reducing the wage 
Trade Liberalization and Wage Dr. Hossam Eldin Mohammed Abdelkader 27/9/2017

inequality, according to the international trade theory. Unfortunately, the empirical evidences do not confirm this assumption (Arbache, 2001). This paper attempts to provide an analytical framework to investigate the impact of trade liberalization, i.e. trade openness, on the wage inequality.

This paper will examine the relationship between the trade openness and wage inequality, by adapting Panel Data Multi-Regression Model. Also, this paper uses some other variables that can help in specifying the major source of wage inequality like, female labor force (\% of total labor force) as the female wage in many countries is less than the male wage. The other source is the leading economic sector which absorbs the biggest share of employment in the economy. Consequently, I use both the employment in industry and the employment in agriculture as a share of total labor force. Additionally, there are other variables such as urban population (\% of total population), and the type of country according to the World Bank Income Classification, because these factors are expected to affect the wage inequality.

This paper is organized as follows. Section 2 presents literature review. Section 3 discusses methodology and data. Section 4 shows models and findings. Finally, section 5 concludes the paper.

\section{Trade Liberalization \& Wage Inequality in Literature}

According to the classical trade theory, it is better for each country to produce the goods, that it is able to produce more, due to supply conditions of resources (human, natural, and capital), and this can happen under the assumption of production specialization. David Ricardo suggests that a country 
Trade Liberalization and Wage $\quad$ Dr. Hossam Eldin Mohammed Abdelkader 27/9/2017

should specialize in producing goods that have the biggest relative advantage of production, i.e. the principle of comparative advantage, and not the biggest absolute advantage of production. according to the last theory, labor is the only production factor, but the effects of free trade on the distribution of income is not clear, since the theory is based on only one factor of production (Arbache, 2001; Karp, 2007).

The model of David Ricardo extended by Heckscher and Ohlin (Husted \& Melvin, 2012). In this new model they assumed that there are two production factors, i.e. labor and capital. According to Heckscher-Ohlin Model, a country which has a comparative advantage will produce goods which are intensive to the factor of production that is relatively more abundant, since this factor is relatively cheaper when compared to the price of the other variables, i.e. relatively scarce factor. Thus, countries in which capital supply is relatively abundant should concentrate on the production of capital intensive goods, and vice-versa for countries whose labor supply is relatively abundant (Arbache, 2001; Leamer, 1995).

The effects of trade on wage inequality are usually analyzed in a Heckscher-Ohlin Model with skilled and unskilled labor as the two factors and developed (North) and developing (South) as the two countries. Trade with the South causes the North to specialize in the production of skill-intensive manufactures, in which it has a comparative advantage because of its relatively large supply of skilled labor, and to reduce production of labor-intensive manufactures. In the North, there is a rise in the relative price of skill-intensive goods and the relative demand for skilled labor, and a widening of the wage gap between skilled and unskilled workers, and vice versa in the South (Wood, 1998; 1997; 1995) 
Trade Liberalization and Wage Dr. Hossam Eldin Mohammed Abdelkader 27/9/2017

The theorem of Stolper and Samuelson (SS) explains the effects of free trade on income distribution among production factors. The basic result of $S S$ is that protectionism increases the returns of the scarce production factor, i.e. labor in developed countries and capital in developing countries (Stolper and Samuelson, 1941; Neary, 2004).

The Factor-Price Equalization Theorem (FPE) extends the analysis of $S S$ to show that, international trade homogenizes the absolute return of production factors among economies. The real wage in developed and developing countries tends to converge to a middle point, so the wages of workers in developed countries decreases and the wages in developing countries increases. The main assumptions used in this theory are: the production factors are qualitatively the same between economies; the production functions are also the same among economies; free movement of goods among economies; there are no transport costs or import taxes; and production factors do not move among economies. Starting from these conditions, the real prices of factors will be the same among countries (Samuelson, 1949; 1948).

The previous assumptions of the theory of international trade was examined by the empirical studies, which tested these assumptions in the developing and developed countries. The results of these studies, which studied the developing countries, was summarized and presented in the following paragraphs. The arrangement of the literature studies was depended on the time dimension, so we arrange it from the oldest to the newest.

Rama (1994) adopted a partial equilibrium approach to examine the relationship between tariffs, employment, and wages in Uruguay. Using industry-level data over a 6 years period, he finds no impact of the reform on wages, but a 
Trade Liberalization and Wage Dr. Hossam Eldin Mohammed Abdelkader 27/9/2017

negative impact on employment. A reduction in the tariffinclusive price of imports by $1 \%$ led to an employment drop of between 0.4 and 0.5 percentage.

Feliciano (1994) analyzed the impact of trade reform on employment and wages using micro data. She used repeated crosssections of household surveys in selected cities to examine the impact of the Mexican trade reforms on wage levels and wage dispersion. She does not find any significant impact of tariff changes on wages but does document an increase in wage dispersion over the period of the reform. She found no impact on aggregate industrial employment, but her sample is better suited for examining wage effects than employment effects.

Currie and Harrison (1997) studied the relationship between changes in trade policies and manufacturing employment at the firm level. Although, trade reforms are generally implemented at the sector level, they show that within a sector that effects vary significantly across firm characteristics such as ownership, i.e. public vs. private, and degree of export orientation. In fact, firm characteristics have a decisive impact on the response to trade reform. Although, the reforms in Morocco had almost no impact on aggregate wages and employment, publicly owned firms and export-oriented firms were strongly affected.

Revenga (1997) analyzed the effect of trade liberalization on employment and wages in the Mexican manufacturing sector. The study finds that many of the rents generated by trade protection were absorbed by workers in the form of a wage premium. Trade liberalization affects firm-level employment and wages by shifting down industry product and labor demand. This in itself may account for 3\% to $4 \%$ decline in real wages. But trade reform also reduces the rents available to be captured by firms and workers, which means additional negative effect on firm-level employment and wages. Revenge (1997) shows that the trade liberalization episode of 1985-87 
Trade Liberalization and Wage Dr. Hossam Eldin Mohammed Abdelkader 27/9/2017

affected firm-level employment and wage through several channels. First, trade reform put downward pressure on employment and wages by shifting down industry product and labor demand, and this may have accounted for $3 \%$ to $4 \%$ decline in real wages on average, and for as much as $10 \%$ to $14 \%$ decline in more affected industries. Generally, the effects of trade liberalization on firm wages appear to have been quite substantial, for an average tariff reduction of $20 \%$ the implied wage response was on range of 5\% to $6 \%$. Moreover, the effects of the removal of quotas rents may have been even greater, although the link to wages in this case proved much harder to document.

Arbache (2001) shows the impact of trade liberalization on labor markets of developing countries. He finds that while the Asian Tiger countries experienced a reduction in wage inequality, but the Latin American and other countries experienced a rise in wage inequality following globalization and trade liberalization. Many developing countries have high degrees of economic openness which, however, does not guarantee incorporation of new technologies, increase in Total Factor Production (TFP), and attraction of foreign direct investment. Human capital, the institutional framework and political stability, for example, all seem to contribute significantly in attracting capital and new technologies. Therefore, openness is a factor that contributes but does not completely determine investment in capital and new technologies. Whatever the reason behind the phenomenon, new technologies seem to play a role in the explanation of the shift of the labor demand.

Arbache, Dickerson and Green (2003) examine the experience of Brazil, concentrated on trade reform in the early 1990s. The data show that wages tend to be lower in traded 
Trade Liberalization and Wage $\quad$ Dr. Hossam Eldin Mohammed Abdelkader 27/9/2017

industries than in non-traded industries, mainly because the traded industries employ workers with lower average education. They investigate both the returns to skill which turned out to be relatively high in Brazil, and sectoral wage differences as trade reform is also likely to signal increased product and labor market competition; and therefore lower rents. Their main conclusions were two results. The first result, allowing for education and experience, wages in the traded sector were lowered substantially by increasing the degree of openness following liberalization, consistent with the view that the reforms raise the degree of competition in traded industries and thereby reduced rents. Wages were also lowered in the nontraded sector, by the effects of other changes such as privatization or deregulation that took place later in the 1990s. Education levels rose the average economy-wide wage level which changes over the period under investigation. The second

result, the increasing openness had differential effects across education groups and within sectors. Across the whole economy, the marginal returns to education were lower in the post-liberalization than the pre-liberalization period, except for college-educated workers the marginal return increased. Within the traded sector, increasing openness was associated with lower wages, but the downward impact of openness on wages was insignificant at the highest two education levels.

Galiani and Porto (2006) explore the links between trade liberalization and skill premium by exploring a historical dataset of Argentine trade policy and labor force surveys. They put together information spanning almost 30 years of recent Argentine history, from 1974 to 2001. They exploit two episodes of trade reforms separated by a decade of reversion to protection. The period under study is one of active and 
Trade Liberalization and Wage $\quad$ Dr. Hossam Eldin Mohammed Abdelkader 27/9/2017

fluctuating trade reforms and wage inequality in Argentina. Tariff reforms accelerated in the late 1970s and early 1980s, stagnated during the 1980s, and picked up further momentum during the 1990s. The skill premium, in contrast, increased during the 1970s, declined during the 1980s, and increased again during the 1990s. In addition, the share of labor income in GDP sharply dropped in the late 1970s, and never recovered. Galiani and Porto (2006) used these historical trends in tariff liberalization, wages and wage inequality to build a better and compelling identification of the impacts of trade policy on the skill premium. Galiani and Porto (2006) find that tariff liberalization hurts all workers but has caused an increase in the skill premium. In particular, the large tariff cuts of the 1970s, i.e. about $70 \%$, can explain up to one-fourth of the observed increase in wage inequality. Instead, the liberalization of the 1990 s can only explain $10 \%$ of the increase in the skill premium. This indicated that tariff reforms contribute to the observed increase in wage inequality but there are other concurrent factors, particularly during the reforms of the 1990s that played a significant role too.

Ferreira, Leite and Wai-Poi (2007) use sample of workers in all sectors of the economy, to quantify the impacts of the 1988-1995 trade liberalization episode on the Brazilian wage distribution. They found that changes in industry wage premium and industry-specific skill premium did not meaningfully contribute to changes in the distribution of hourly wages. Trade reforms contribute to the observed reduction in inequality, but this happened through other channels. The first was tradeinduced changes in employment levels across sectors, industries and formality categories, i.e. formal, informal, self-employed, and employer. The reallocation of workers that their model 
Trade Liberalization and Wage Dr. Hossam Eldin Mohammed Abdelkader 27/9/2017

predicted to have arisen from changes in levels of protection, exchange rates, import penetration and export shares between 1988 and 1995 accounts for more than $50 \%$ of the observed changes in 3 out of 4 measures of inequality in hourly wages. The other channel through which trade reform is likely to affect the distribution of wages is through changes in the economywide skill premium. Ferreira, Leite and Wai-Poi (2007) results suggest that trade liberalization did play an important role in the reduction of wage inequality in Brazil during 1988-1995. The counterfactual wage growth incidence curve that includes the combined wage and employment effects mandated by changes in trade variables accounted for $59 \%$ of the observed change in the Theil-L index, $61 \%$ of the change in the Gini coefficient, and $76 \%$ of the change in the Theil-T index. Among the combined effects, changes in occupation and employment levels across industries were the most important.

\section{Methodology \& Data}

\subsection{Methodology}

This research is following deductive methodology to test the theory in reality, so that it uses econometric method. The econometric technique used here is the panel data, which are "data for multiple entities in which each entity is observed at two or more time periods". We should differentiate between balanced and unbalanced panel. A balanced panel has all its observations, that is, the variables are observed for each entity and each time period. A panel that has some missing data for at least one-time period for at least one entity is called an unbalanced panel (Stock and Watson, 2003). In this study, I will 
use unbalanced panel as the data not available for all counties and all time period.

According to Verbeek (2012), the panel data fixed effect linear regression model in case of the intercept, $\alpha_{i}$, vary over individual units $i$, could be presented as (1), where dependent variable is $y_{i t}$ for unit $i$ at time $t$, and $\beta$ is the estimated coefficient matrix for the relationship between $y$ and $x$.

$$
y_{i t}=\alpha_{i}+x_{i t}^{\prime} \beta+\varepsilon_{i t}, \quad \varepsilon_{i t} \sim \operatorname{IID}\left(0, \sigma_{\varepsilon}^{2}\right)
$$

where $x_{i t}$ are independent variables which are independent of all error term, $\varepsilon_{i t}$. We can represent (1) in case of using dummy variables for each unit, $i$, i.e. $D_{i}$, where $D_{i j}=1$ when $i=j$ and 0 elsewhere. Under fixed effect model, equation (2) shows the form of (1) in case of Least Squares Dummy Variable (LSDV) estimator method.

$$
y_{i t}=\sum_{j=1}^{N} \alpha_{j} D_{i j}+x_{i t}^{\prime} \beta+\varepsilon_{i t}
$$

The Ordinary Least Squares (OLS) method will be used to estimate $\alpha$ and $\beta$ parameters. Consequently, the estimated $\beta$ takes the form (3), where the covariance matrix for fixed effects estimator $\hat{\beta}_{F E}$ is (4), and variance of error tem is (5).

$$
\begin{gathered}
\hat{\beta}_{F E}=\left(\sum_{i=1}^{N} \sum_{t=1}^{T}\left(x_{i t}-\bar{x}_{i}\right)\left(x_{i t}-\bar{x}_{i}\right)^{\prime}\right)^{-1} \sum_{i=1}^{N} \sum_{t=1}^{T}\left(x_{i t}\right)\left(y_{i t}-\bar{y}_{i}\right)^{\prime} \\
V\left\{\hat{\beta}_{F E}\right\}=\sigma_{\varepsilon}^{2}\left(\sum_{i=1}^{N} \sum_{t=1}^{T}\left(x_{i t}-\bar{x}_{i}\right)\left(x_{i t}-\bar{x}_{i}\right)^{\prime}\right)^{-1}
\end{gathered}
$$




$$
\begin{gathered}
\sigma_{\varepsilon}^{2}=\frac{1}{N(T-1)} \sum_{i=1}^{N} \sum_{t=1}^{T}\left(y_{i t}-\hat{\alpha}_{i}-x_{i t}^{\prime} \hat{\beta}_{F E}\right)^{2} \\
\sigma_{\varepsilon}^{2}=\frac{1}{N(T-1)} \sum_{i=1}^{N} \sum_{t=1}^{T}\left(y_{i t}-\bar{y}_{i}-\left(x_{i t}-\bar{x}_{i}\right) \hat{\beta}_{F E}\right)^{2}
\end{gathered}
$$

The estimated model here is trying to uncover the impact of trade liberalization on wage inequality in a sample of countries around the world. The average applied tariff rate is used as the measure of trade liberalization, however, the suitable measure of wage inequality is a sophisticated process. One of methods that usually used to measure wage inequality is the Theil inequality index, $T I$. This index can be expresses as (6)

$$
T I=\sum_{i=1}^{n}\left(\frac{P_{i}}{P}\right)\left(\frac{\bar{Y}_{i}}{\bar{Y}}\right)\left(\log \left(\frac{\bar{Y}_{i}}{\bar{Y}}\right)\right)
$$

Where $\bar{Y}_{i}$ is the average pay of the $i^{\text {th }}$ region (or sector), i.e. $\bar{Y}_{i}=\frac{Y_{i}}{P_{i}}$, and $P_{i}$ is the number of individuals employed in the $i^{\text {th }}$ region (or sector) and $Y_{i}$ is the total pay earned by them. Moreover, $\bar{Y}$ is the average pay of all the regions (or sectors) of the country, i.e. $\bar{Y}=\frac{Y}{P}$, and $P$ is the number of individuals employed in all regions (or sectors) of the country.

The Theil inequality index in (6) can also expressed as (7), where $\left[\frac{Y_{i}}{Y}\left\{\log \left(\frac{Y_{i}}{P_{i}} / \frac{Y}{P}\right)\right\}\right]$ is the Theil element for $i^{\text {th }}$ region (or sector). 


$$
T=\sum_{i=1}^{n}\left(\frac{\bar{Y}_{i}}{\bar{Y}}\right)\left\{\log \left(\frac{Y_{i}}{P_{i}} / \frac{Y}{P}\right)\right\}
$$

Other variables will be used in estimated model are share of female in labor force, the employment in industry as a share a of total labor force, the employment in agriculture as a share of total labor force, urban population as a share of total population, and the type of country according to the World Bank Income Classification ${ }^{1}$.

\section{.3 Data}

The sample size of this research is consists of 27 countries $^{2}$ divided into four groups low-income (6 countries), lower-middle income (8 countries), upper-middle income (8 countries), and high-income (5 countries), for 10 years from 1987 to 1996. The size of sample, countries and period of time, determined mainly by the availability of data. Another reason of selecting the period of time, 1987-1996, is many countries adopted the trade liberalization in this period. Table (1) summarizes the data definition and sources.

Table (1)

Symbol, Definition, and Sources of Data

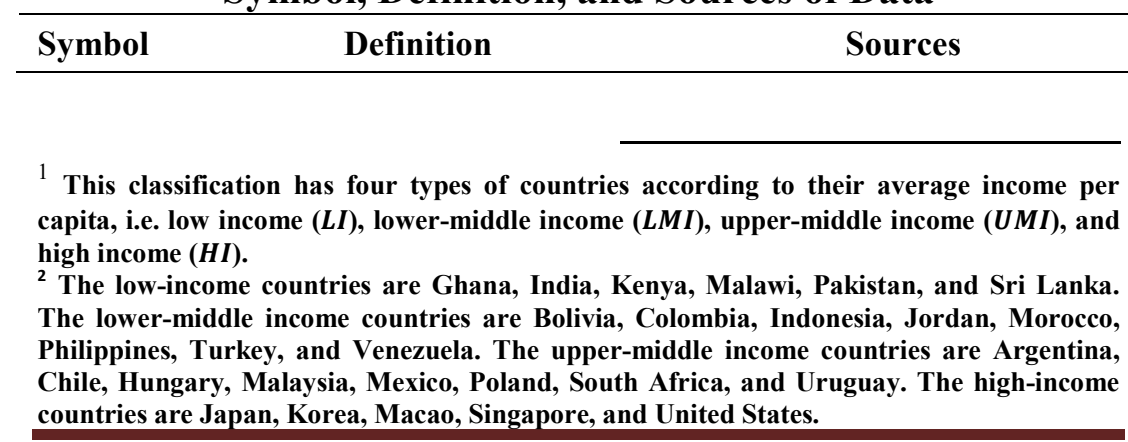




\begin{tabular}{|c|c|c|}
\hline \multicolumn{3}{|c|}{ Trade Liberalization and Wage } \\
\hline$W I$ & Wage inequality index & $\begin{array}{c}\text { The University of Texas: } \\
\text { Inequality Project (UTIP) } \\
\text { Database. }\end{array}$ \\
\hline$T$ & Average rate of tariff & $\begin{array}{l}\text { UNCTAD: TRAINS } \\
\text { Database. }\end{array}$ \\
\hline$F$ & Female labor force & \\
\hline EI & Employment in industry & The World Bank: World \\
\hline$E A$ & employment in agriculture & Development Indicator (WDI). \\
\hline$U P$ & Urban population & \\
\hline$D_{1}$ & Dummy variable for LI countries & \\
\hline$D_{2}$ & $\begin{array}{l}\text { Dummy variable for LMI } \\
\text { countries }\end{array}$ & The World Bank: Income \\
\hline$D_{3}$ & $\begin{array}{l}\text { Dummy variable for UMI } \\
\text { countries }\end{array}$ & \\
\hline$T D_{1}$ & $\begin{array}{l}\text { Interaction variable between } T \\
\text { and } D_{1}\end{array}$ & \\
\hline$T D_{2}$ & $\begin{array}{l}\text { Interaction variable between } T \\
\text { and } D_{2}\end{array}$ & \\
\hline$T D_{3}$ & $\begin{array}{l}\text { Interaction variable between } T \\
\text { and } D_{3}\end{array}$ & \\
\hline
\end{tabular}

The share of females in labor market is used as indicator for gender inequality. Moreover, economy leading sector, i.e. industry or agriculture, is expected to explain a part of inequality in wages. Furthermore, population size in urban to the total population may be a good indicator for wage inequality, as in the countries where population is distributed equally among regions, they may have more wage equality comparing to those countries where their population distributed unequally among their regions. Finally, the type of country, i.e. dummy variables $^{3}$, is expected to explain a part of wage inequality among different countries.

\footnotetext{
${ }^{3}$ In case of low income countries $D_{1}=1$, and $D_{2}=D_{3}=0$, for lower-middle income countries $D_{2}=1$, and $D_{1}=D_{3}=0$, and for upper-middle income countries $D_{3}=1$, and $D_{1}=D_{2}=0$, while, for high income countries $D_{1}=D_{2}=D_{3}=0$.
} 
Trade Liberalization and Wage Dr. Hossam Eldin Mohammed Abdelkader 27/9/2017

Figure (1) shows the average value of wage inequalities in different regions of the world, according to the level of income. It is clear that low income countries have the highest inequality level, while high income countries have the lowest level of inequality in wages. Also, it is clear that when a country is moving from low income category to high income one the average level of wage inequality is decreasing.

Figure (2) shows average values of other variables according to the income level. The highest level of tariff means the lowest level of trade liberalization. Low-income countries, as expected, have the highest average of tariff, while highincome countries have the minimum average of tariff. The share of female is high in both low income and high income. In low income countries women work to share in the cost of live, while in high income countries women work to be self-dependent and to achieve their goals. Employment in industry is increasing when level of income increasing, while employment in agriculture is going in the opposite direction. Additionally, when a country is moving toward higher level of income the urban population is increasing. See Table (2) for more statistical descriptive details.

Table (2)

Descriptive Analysis of Variables

\begin{tabular}{cccccc}
\hline Variable & Obs. & \multicolumn{6}{c}{ Mean } & Std. Dev. & Min & Max \\
\hline$W I$ & 257 & 0.056 & 0.032 & 0.004 & 0.207 \\
$T$ & 234 & 18.965 & 15.319 & 0.000 & 98.8 \\
$F$ & 270 & 36.780 & 7.617 & 18.79 & 50.91 \\
$E I$ & 187 & 26.487 & 7.377 & 8.3 & 46.7 \\
$E A$ & 187 & 21.268 & 20.122 & 0.000 & 69.1 \\
$U P$ & 270 & 59.127 & 24.772 & 10.82 & 100 \\
\hline \multicolumn{5}{c}{ Low Income Countries (LI) } \\
\hline
\end{tabular}




\begin{tabular}{|c|c|c|c|c|c|}
\hline \multicolumn{6}{|c|}{ Trade Liberalization and Wage } \\
\hline$W I$ & 49 & 0.0875 & 0.040 & 0.028 & 0.207 \\
\hline$T$ & 53 & 36.443 & 20.522 & 13.5 & 98.8 \\
\hline$F$ & 60 & 38.303 & 10.419 & 22.75 & 50.91 \\
\hline EI & 27 & 18.282 & 3.738 & 10.1 & 25.7 \\
\hline$E A$ & 27 & 48.122 & 14.53 & 18.9 & 69.1 \\
\hline$U P$ & 60 & 23.651 & 8.872 & 10.82 & 40.96 \\
\hline \multicolumn{6}{|c|}{ Lower-Middle Income Countries (LMI) } \\
\hline$W I$ & 80 & 0.0693 & 0.0201 & 0.0324 & 0.1166 \\
\hline$T$ & 69 & 19.5029 & 6.6308 & 7 & 32.9 \\
\hline$F$ & 80 & 32.1774 & 7.0126 & 18.79 & 44.08 \\
\hline$E I$ & 59 & 22.3678 & 6.4249 & 8.3 & 31.5 \\
\hline$E A$ & 59 & 27.0746 & 21.6738 & 1 & 56.2 \\
\hline$U P$ & 80 & 59.5840 & 15.7750 & 27.9 & 88.54 \\
\hline \multicolumn{6}{|c|}{ Upper-Middle Income Countries (UMI) } \\
\hline WI & 78 & 0.0432414 & 0.0214 & 0.0043 & 0.0937 \\
\hline$T$ & 67 & 14.1284 & 4.9822 & 8 & 29.1 \\
\hline$F$ & 80 & 37.7818 & 5.4793 & 29.59 & 45.83 \\
\hline$E I$ & 54 & 29.6167 & 4.5262 & 21.5 & 38 \\
\hline$E A$ & 54 & 15.0907 & 10.3931 & 0 & 30.9 \\
\hline$U P$ & 80 & 70.5095 & 14.2668 & 47.46 & 90.66 \\
\hline \multicolumn{6}{|c|}{ High Income Countries (HI) } \\
\hline$W I$ & 50 & 0.0260 & 0.0136 & 0.0041 & 0.0660 \\
\hline$T$ & 45 & 4.76 & 5.418 & 0 & 22.9 \\
\hline$F$ & 50 & 40.7172 & 2.3021 & 36.84 & 45.11 \\
\hline EI & 47 & 32.7766 & 4.8305 & 24.1 & 46.7 \\
\hline$E A$ & 47 & 5.6511 & 6.3723 & 0 & 21.9 \\
\hline$U P$ & 50 & 82.758 & 14.9003 & 61.6 & 100 \\
\hline
\end{tabular}


Figure (1)

Average Wage Inequality

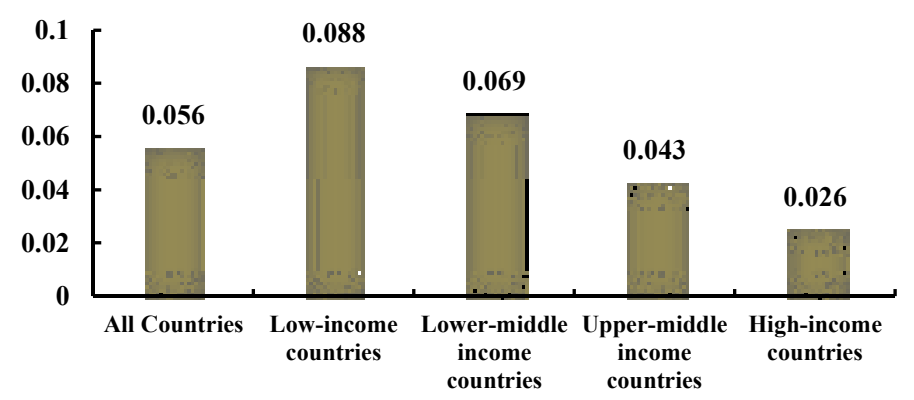

Figure (2)

Average Values of Variables

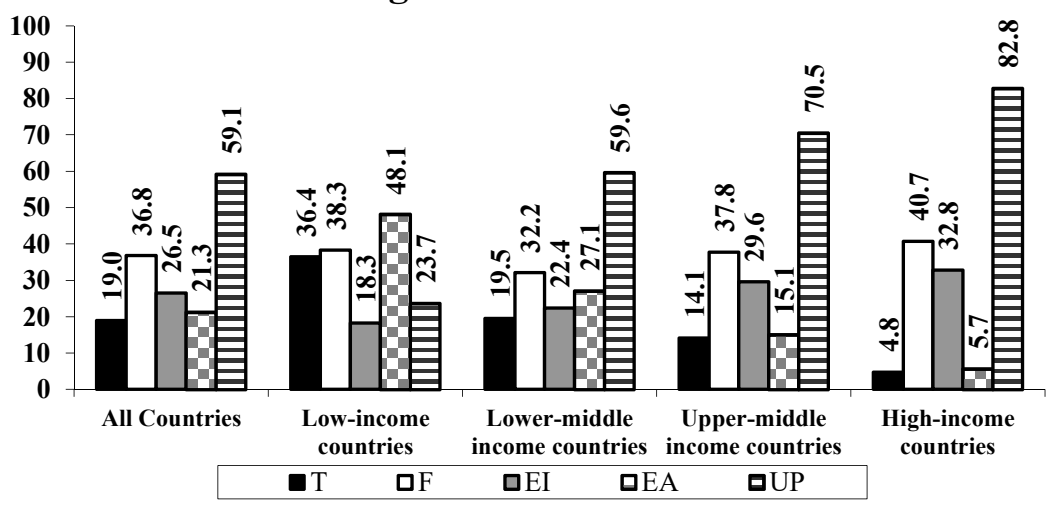

\section{Models and Empirical Findings}

The estimated model takes three forms. The first, I will call it Model (I), and it shows the expected relationship between wage inequality and trade liberalization. This model summarized as follow: 
Trade Liberalization and Wage Dr. Hossam Eldin Mohammed Abdelkader 27/9/2017

$$
\begin{gathered}
W I_{i t}=\alpha_{i}+\beta_{1} T_{i t}+\beta_{2} F_{i t}+\beta_{3} E I_{i t}+\beta_{4} E A_{i t}+\beta_{5} U P_{i t} \\
+\varepsilon_{i t}
\end{gathered}
$$

Where $i$ is the country reference, and $t$ is the time index.

The second model, Model (II), is adding dummy variables which reflect the impact of country income level on wage inequality.

$$
\begin{gathered}
W I_{i t}=\alpha_{i}+\beta_{1} T_{i t}+\beta_{2} F_{i t}+\beta_{3} E I_{i t}+\beta_{4} E A_{i t}+\beta_{5} U P_{i t} \\
+\delta_{1} D_{1, i t}+\delta_{2} D_{2, i t}+\delta_{3} D_{3, i t}+\varepsilon_{i t}
\end{gathered}
$$

The third model, Model (III), is adding the interaction between the level of income and the level of trade liberalization on the wage inequality and it take the following form.

$$
\begin{gathered}
W I_{i t}=\alpha_{i}+\beta_{1} T_{i t}+\beta_{2} F_{i t}+\beta_{3} E I_{i t}+\beta_{4} E A_{i t}+\beta_{5} U P_{i t} \\
+\delta_{1} D_{1, i t}+\delta_{2} D_{2, i t}+\delta_{3} D_{3, i t}+\eta_{1} T D_{1, i t} \\
+\eta_{2} T D_{2, i t}+\eta_{3} T D_{3, i t}+\varepsilon_{i t}
\end{gathered}
$$

\subsection{All Countries Sample}

In all countries sample, the trade liberalization, measured by average tariff, has negative impact on wage inequality as increase in tariff, less trade liberalization, will decrease the wage inequality. Consequently, this refers to the direct relationship between trade liberalization and wage inequality, but this impact equals zero and insignificant statistically. In addition, the increase is share of female in labor force decreases wage inequality, as it decreases the gender discrimination against women, and this impact is significant at $1 \%$ level of significance, see Table (3).

Moreover, the increase in employment in the leading sector in economy, i.e. industry or agriculture, decreases the 
Trade Liberalization and Wage $\quad$ Dr. Hossam Eldin Mohammed Abdelkader 27/9/2017

wage inequality, however, the impact of industry is greater than agriculture, and both of them are significant at $1 \%$. However, the urban population from the total population has a negative small impact, but it is insignificant. Furthermore, the middle income countries have a higher level of wage inequality comparing with high income countries, and this difference is significant at $5 \%$ and $1 \%$. But, the impact of interaction variables is insignificant in all models, i.e. I, II, and III.

Table (3)

The Estimated Models of All Countries

\begin{tabular}{|c|c|c|c|}
\hline \multirow{2}{*}{ Variables } & \multicolumn{3}{|c|}{$W I$} \\
\hline & Model (I) & Model (II) & Model (III) \\
\hline$\alpha$ & $0.1979^{*}$ & $0.1698^{*}$ & $0.1872^{*}$ \\
\hline$\alpha$ & {$[9.70]$} & {$[7.90]$} & [7.93] \\
\hline$T$ & -0.0000 & -0.0000 & -0.0012 \\
\hline & {$[-0.00]$} & {$[-0.00]$} & {$[-1.09]$} \\
\hline$F$ & $-0.0013^{*}$ & $-0.0010^{*}$ & $-0.0010^{*}$ \\
\hline & $-0.0028 *$ & $-0.0027 *$ & $-0.0030 *$ \\
\hline$E I$ & {$[-9.33]$} & {$[-9.00]$} & {$[-10.00]$} \\
\hline$E A$ & $-0.0007 *$ & $-0.0007 *$ & $-0.0007^{*}$ \\
\hline & {$[-7.00]$} & {$[-7.00]$} & {$[-7.00]$} \\
\hline$U P$ & -0.0002 & -0.0001 & -0.0002 \\
\hline & {$[-1.00]$} & {$[-1.00]$} & $\left.\begin{array}{ll}{[-2.00} & 0\end{array}\right]$ \\
\hline$D_{1, i t}$ & & {$[1.36]$} & {$[-0.60]$} \\
\hline$D_{2, i t}$ & & $0.0192 *$ & $0.0263^{*}$ \\
\hline & & $0.0094 * *$ & $0.0047]$ \\
\hline$D_{3, i t}$ & & [2.24] & {$[0.67]$} \\
\hline$T D_{1, i t}$ & & & 0.0014 \\
\hline & & & 0.0004 \\
\hline$T D_{2, i t}$ & & & {$[1.00]$} \\
\hline$T D_{3, i t}$ & & & 0.0012 \\
\hline$F$ & 33.19 & 26.26 & 20.58 \\
\hline$R^{L}$ & 0.5236 & 0.5867 & 0.6096 \\
\hline$R_{a d i}^{L}$ & 0.5078 & 0.5643 & 0.5800 \\
\hline No. Obs. & 157 & 157 & 157 \\
\hline
\end{tabular}


Trade Liberalization and Wage $\quad$ Dr. Hossam Eldin Mohammed Abdelkader 27/9/2017

All three models have approximately similar results. The Ftest values were between 20.58 and 33.19 which refers to the significance of the model as whole, the determination coefficients, $R^{2}$, were between $52 \%$ and $61 \%$, and adjusted values are close to this range, and the number of observations is 157 .

\subsection{Low-Income Countries Sample}

In case of low-income countries, all three models ended up with exactly identical results, so that I present it in one model as follow. In this model trade liberalization leads to higher wage inequality, but it is still insignificant even at $10 \%$. The increase in female share in labor market increases wage inequality; because in these countries there is a clear wage discrimination against women, and this impact is significant at $1 \%$. However, the impact of employment in industry is negative and insignificant on wage inequality, but the employment in agriculture increases the wage inequality, and statistically significant at $10 \%$; because the worse conditions of this sector and the absence of enough subsidies for farmers. Finally, urban population has significant impact on wage inequality in low income countries. Furthermore, all dummy and interactive variables were insignificant; thus I exclude all of them. In addition, F-test value is 14.20 , which refers to the significance of the model as whole, the determination coefficient, $R^{2}$, is $83 \%$ and adjusted value of it equals $77 \%$, and the number of observations is 21 .

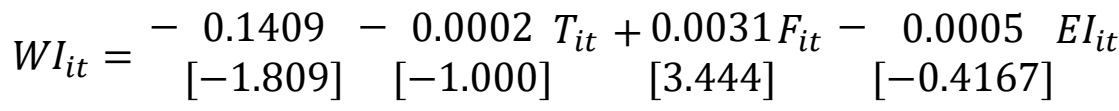

$$
\begin{aligned}
& +0.0007 E A_{i t}+0.0040 U P_{i t} \\
& \text { [1.750] [4.444] } \\
& R^{2}=0.83, \quad R_{a d j}^{2}=0.77, \quad F=14.20, \quad \text { No.Obs. }=21
\end{aligned}
$$




\subsection{Lower-Middle Income Countries Sample}

An increase in trade liberalization index will rise the wage inequality level in lower-middle countries, and this impact is significant at $5 \%$. Although, any increase in female share in labor market leads to decrease in wage inequality, but it is insignificant. However, the impact of leading sector is clear, as an increase in employment in industry or agriculture leads to enhancement in wage equality, but the impact of former is higher, and both of them have significant impact. Urban population does not have a significant impact in these countries on wage inequality. Additionally, the dummy variable of these countries has no significant impact on wage inequality, and even the interaction variable is insignificant. Finally, F-test value is 4.32, $R^{2}$ value is $49 \%$ and its adjusted value is $38 \%$, and the number of observations is 50 .

$$
\begin{gathered}
W I_{i t}=\begin{array}{c}
0.2461-0.0019 \\
{[4.609] \quad[-2.375]}
\end{array} T_{i t}-0.0003 F_{i t}-0.0034 E I_{i t} \\
-0.0007 E A_{i t}-0.0004 U P_{i t}-0.0225 D_{2, i t}+0.0004 T D_{2, i t} \\
{[-2.333] \quad[-1.333] \quad[-1.023]} \\
R^{2}=0.49, \quad R_{a d j}^{2}=0.38, \quad F=4.32, \quad \text { No. Obs. }=50
\end{gathered}
$$




\subsection{Upper-Middle Income Countries Sample}

Trade liberalization has an insignificant negative impact on wage inequality in upper-middle income countries, which means more trade liberalization leads to less wage inequality. An increase in the share of female in labor market helps in rising the wage equality, but this impact is insignificant. Leading sector will enhance wage equality, and it is significant in case of industry or agriculture sectors. Moreover, when size of urban population increases the wage inequality will increase, and the interaction between the measure of income and trade liberalization has a negative impact on wage inequality at $5 \%$. Finally, the size of sample is 44, F-test is 18.41, and determination coefficient is $78 \%$.

$$
\begin{aligned}
& W I_{i t}=\frac{0.1203}{[3.477]}+0.0013 T_{i t}-0.0006 F_{i t}-0.0023 E I_{i t} \\
& \text { - } 0.0008 E A_{i t}+0.0005 U P_{i t}-0.0021 T D_{2, i t} \\
& {[-2.000] \quad[2.450] \quad[-2.333]} \\
& R^{2}=0.78, \quad R_{a d j}^{2}=0.73, \quad F=18.41, \quad \text { No. Obs. }=44
\end{aligned}
$$

\subsection{High-Income Countries Sample}

In case of high-income countries, an increase in the level of trade liberalization will decrees wage inequality, but unfortunately, it is insignificant even at $10 \%$. The impact of female in labor market, leading sector, and urban population are the same as in the sample of all countries. In addition, number of observations is 44, F-test is 18.41, which means the model is significant, and the explanation power of the model is $78 \%$. 
Trade Liberalization and Wage $\quad$ Dr. Hossam Eldin Mohammed Abdelkader 27/9/2017

$$
\begin{gathered}
W I_{i t}=\begin{array}{c}
0.3893+0.0002 T_{i t}-0.0057 F_{i t}-0.0017 E I_{i t} \\
{[7.693] \quad[-0.222] \quad[-5.700] \quad[-4.250]}
\end{array} \\
-0.0015 E A_{i t}-0.0008 U P_{i t}+0.0024 T D_{3, i t} \\
{[-1.875] \quad[-8.000] \quad[3.000]} \\
R^{2}=0.78, \quad R_{a d j}^{2}=0.73, \quad F=18.41, \quad \text { No.Obs. }=44
\end{gathered}
$$

\section{Conclusion}

This research investigates the linkage between trade liberalization and wage inequality in a sample of 27 countries during 10 years, 1987-1996. Panel data regression model is used to estimate this relationship.

The results of estimated models confirm that trade liberalization has no impact on wage inequality in the sample of all countries. However, an increase in trade liberalization leads to higher level of wage inequality in low income and lowermiddle income countries, but this impact is only significant in case of lower-middle income countries. However, higher trade liberalization leads to lower level of wage inequality in case of upper-middle income and high income countries, but this impact is statistically insignificant. Additionally, results confirm that the impact of trade liberalization on countries depends on the type of the country, thus when the country is moving towards rich countries or developed countries then trade liberalization will decrease the wage inequality, and vise a vice, if the country is low income or lower-middle income the trade liberalization will enlarge the wage inequality.

Moreover, the rise in female share in labor market enhance the wage equality, and higher level of employment in leading sector of production, i.e. industry or agriculture, enhance the wage equality in the economy. Although, the urban population size has an ambiguous effect on wage inequality. 


\section{References}

Abacha, Jorge Saba, Andy Dickerson and Francis Green (2003), "Trade liberalization and wages in developing countries", Department of Economics, University of Kent.

Arbache, Jorge Saba (2001), 'Trade liberalization and labor market in developing countries: theory and evidence', University of Kent at Canterbury.

Currie, Janet and Ann Harrison, (1997), 'Sharing the Costs: The Impact of Trade Reform on Capital and Labor in Morocco', Journal of Labor Economics, Vol. 15, No. 3, Part 2: July.

Feliciano, Zadia M, (1994), 'Workers and trade liberalization: the impact of trade reform in Mexico on wage and employment', Cambridge, MA: Harvard University.

Ferreira, Francisco H.G., Phillippe G. Leite and Matthew WaiPoi, (2007), 'Trade liberalization, employment flows and wage inequality in Brazil', Washington, DC, World Bank, World Bank Policy Research Working, No. 4108, January.

Galiani, Sebastian and Guido G. Porto, (2006), 'Trends in Tariff Reforms and Trends in Wage Inequality', Washington, D. C., World Bank, World Bank Policy Research Working Paper, No. 3905, May.

Gottschalk, P. and Smeeding, T.M. (1997), 'Cross-national comparisons of earnings and income inequality', Journal of Economic Literature, XXXV.

Husted, Steven \& Melvin, Michael (2012) International Economics. 9th Ed, Boston, Pearson.

Karp, Larry, (2007) 'International trade', Lecture notes, Department of Economics, University of Southampton.

Kruse, Douglas L., (1988), 'International Trade and the Labor Market Experience of Displaced Workers', Industrial and Labor Relations Review, Vol. 41, No. 3, April. 
Trade Liberalization and Wage $\quad$ Dr. Hossam Eldin Mohammed Abdelkader 27/9/2017

Leamer, Edward E., (1995), 'The Heckscher-Ohln model in theory and practice' Princeton University, Princeton Studies in International Finance, No. 77, February.

Neary, J. Peter, (2004), 'The Stolper-Samuelson Theorem', Prepared for Encyclopedia of World Trade Since 1450, ed. J.J. McCusker et al., New York: Macmillan Reference, University College Dublin and CEPR, February.

Rama, Martin, (1994), 'The labor market and trade reform in manufacturing', In The effect of protectionism on a small country, edited by Michael Connolly and Jaime de Melo. Washington, DC, World Bank, World Bank Regional and Sectoral Studies.

Revenga, Ana, (1997), 'Employment and Wage Effects of Trade Liberalization: The Case of Mexican Manufacturing', Journal of Labor Economics, Vol. 15, No. 3, Part 2: July.

Samuelson, P.A. (1948), 'International trade and the equalization of factor prices', Economic Journal, 58: 163184.

Samuelson, P.A. (1949), International factor price equalization once again', Economic Journal, 59: 181-197.

Stock, James H. and Mark W. Watson, (2003), "Introduction to econometrics', Boston, Pearson Education, Inc.

Stolper, Wolfgang and Paul A. Samuelson (1941). "Protection and Real Wages." Review of Economic Studies, 9: 58-73.

Verbeek, Marno (2012) A guide to Modern Econometrics. 4th Ed, England, John Wiley \& Sons, Ltd.

Wood, Adrian, (1995), 'How trade hurt unskilled workers', Journal of Economic Perspectives, vol. 9, no. 3, pp. 57-80.

Wood, Adrian, (1997), 'Openness and wage inequality in developing countries: the Latin American challenge to East 
Trade Liberalization and Wage $\quad$ Dr. Hossam Eldin Mohammed Abdelkader 27/9/2017

Asian conventional wisdom', World Bank Economic

Review, vol. 11, no. 1, pp. 33-57.

Wood, Adrian, (1998), 'Globalisation and the Rise in Labour Market Inequalities', The Economic Journal, Vol. 108, No. 450, Sep. 